\title{
Factors Affecting Islamic and Conventional Mutual Funds' Returns. A Comparative Analysis of Different Classes of Funds in Pakistan
}

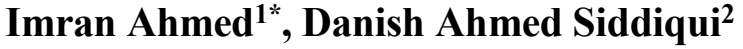

${ }^{1}$ Research Scholar, Karachi University Business School, University of Karachi, Karachi, PAKISTAN

${ }^{2}$ Associate Professor, Karachi University Business School, University of Karachi, Karachi, PAKISTAN

Corresponding Contact:

Email: imran.ahmed790@yahoo.com

Manuscript Received: 07 Feb 2019 - Revised: 05 April 2019 - $\quad$ Accepted: 19 April 2019

\begin{abstract}
This study aims to analyze and investigate the factors influencing returns of Islamic and conventional mutual funds in Pakistan. Furthermore, this study aims to investigate whether macroeconomic and systematic factors affect Shariah compliant Equity, Income and Assets allocation Mutual Funds differently as compared their conventional counterparts. Different statistical techniques like correlation and regression analysis were applied to study their effect. The study concluded that macro-economic factors have an impact on both conventional and Islamic mutual funds however their impact seems to be insignificant at large. Overall funds behaved negatively with discount rate, inflation and GDP, whereas positively with trade and market index. Apart from income funds that were affected positively with discount rate. Furthermore, income funds were not affected by market index. Moreover, inflation and GDP that is usually backed by higher interest rates, also effects overall returns negatively. There was no significant difference in the behavior among the Islamic and conventional funds with respect to the above-mentioned factors. Lastly, there was high correlation among both the equity and asset allocation based mutual funds (both Islamic and conventional). It was also found that asset allocation funds had close resemblance to equity-based funds as compared to incomebased funds in term of factors influencing their returns, which suggested that most of the asset allocation funds have more portion of equity as compared to debt and could be considered high risk. Hence, they seem to be against Modern portfolio theory Markowitz (1952) presuming it to be in a minimum level of risk.
\end{abstract}

Key Words: Mutual funds, equity, income, asset Allocation, regression analysis, macroeconomic variables

\section{INTRODUCTION}

Islamic Finance has amazed the world by its growth rate. There has also been a flow of interest in Islamic finance from all over the world including non-Muslim countries such as the UK, Luxembourg, South Africa, and Hong Kong. Islamic finance has appeared as a 
valuable tool for financing development worldwide over the past decade, as well as in nonMuslim countries. Major financial markets are seeing hard evidence that Islamic finance has already been mainstreamed within the global financial system - and that it has the potential to grow and to help address the challenges of ending life-threatening poverty and enhancing shared prosperity.

Islamic finance is based on Sharia rule, asset-backed, ethical, sustainable, environmentallyand socially-responsible finance. It promotes risk sharing, profit sharing and connects the financial sector with the real economy, and stresses financial inclusion and social welfare. Since it is conceptually and structurally different from conventional funds, there is a need to ascertain that whether, and how, it behaves differently with respect to macro-economic factors and systematic risk. The difference is just in terms of definitions and legality or they are structurally and operationally different, having different risk and return framework, and additionally how they behave with respect to systematic shocks. The base line research was done by different studies on international level regarding effect of macro-economic variables on financial market.

Aggarwal and Saqib (2017) examined the influence of macro-economic variables of India and USA on Indian Stock Market. Akbar and Afiezan (2018) investigated the impact of corporate fundamentals and macro-economic variables on stock price of shariah compliant index in Jakarta (JII). Moya-Martínez et al., (2015) examined the relationship between Interest rate and stock market return in Spanish Stock market. Wasseja et al. (2015) investigated and examined the causal relationship between Kenya stock price and macroeconomic variables. Kumar (2017) Investigated effect of macro-economic variables on Bombay Stock Exchange (BSE-100 India stock market). The study investigated external debts, inflation and macro-economic variables as independent variables and BSE-100 as the dependent variable. Sinha and Kohli (2013) investigated the relationship between foreign exchange rate and stock returns and examine how they were influenced by macro-economic variables. Rizky et al. (2013) study investigated the relationship between Jakarta stock Exchange Islamic Index and macro-economic variables. Singh (2015) analyzed the relationship between Bombay Stock exchange (Indian Stock Market) and macro-economic variables. Azizah and Satria (2016) investigated the relationship between Indonesian Sharia Stock Index (ISSI) and macro-economic variables as independent variables.

The above-mentioned studies are mostly conducted in developed countries and some on developing countries. Furthermore, most of them have taken conventional market index returns as dependent variables, and only a few have taken sharia complaint indices as dependent variables, but no distinction is analyzed in terms of Islamic and conventional nature of these variables. Moreover, no such study has been conducted on mutual funds and differences among their types. Most of the mutual funds use market returns as their benchmark but are otherwise unique in terms of types and expertise. To overcome these gaps, we conducted this study on the mutual fund industry on Pakistan.

Pakistan is unique country in many regards. Firstly, it a developing country where financial markets and products are still in a developing phase. Secondly, it also has a huge infrastructure of both Islamic and conventional financial institutions and products. Thirdly, the mutual funds industry is developing fast and almost at equal footing with their conventional counterparts. These places provide Pakistan a unique standing among other countries. Hence, there was a need to explore how differently macro-economic factors influences shariah compliant mutual funds and conventional mutual funds returns in the context of Pakistan. 
This study filled that gap more comprehensive comparison of effect of macro-economic variables on conventional Equity Index with its Islamic Index, conventional Fixed Income with its counterpart Islamic Fixed Income (Sukuk in Islamic Finance) and Convention mixture of fixed income and equity called Asset Allocation funds with its counterpart called sharia compliant Asset Allocation mutual funds in Pakistan. Both funds followed portfolio theory and assumed to have no significant difference, the only difference seems to be in legal nature that prohibited firm that engaged in non-sharia compliant activities to be included in shariah compliant funds. Whether this culminates into real structural difference given them unique identity has yet to be seen. One of the factors to judge this is to analyses their behavior with respect to systematic shocks.

As discussed earlier, Pakistan's Mutual funds industry is relatively new. National Investment Trust (NIT) and Investment Corporation of Pakistan (ICP) were the only two government owned organizations from which mutual funds started in 1960. Privatization of Pakistan financial sector started in 1990 and eased up the way for Investor to invest in financial sector of Pakistan. Investment Corporation of Pakistan (ICP) was privatized in 2000, after which it gained momentum, and Pakistan's mutual funds industry witnessed vigorous growth. Local and foreign investors showed keen interest in mutual funds of Pakistan and the corporation has now become a leading Non-Banking Financial Institution (NBFI) and is regulated by Security \& Exchange Commission of Pakistan (SECP). Between 2001 to 2005 open-ended funds grew to 30 and by 2010 it grew 300\% and open-ended fund increased to 105.

For the last three years, Pakistan's mutual fund industry is growing by more than $6 \%$. Net Asset Value (NAV) of the industry has reached PKR 622 billion by June-2017 (Pakistan \& Gul Economist). In June 2015, Pakistan's first Real Estate Investment Trust fund (REIT) has also been launched. The State Bank has permitted mutual funds to make foreign investment up to $30 \%$. By the end of financial year 2017, the number of open-ended funds reached 211, closed fund and pension funds climbed to 3 and 19 respectively. 233 Asset Management companies (AMC's) are under the umbrella of Security \& Exchange Commission of Pakistan (SECP).

Different studies have been carried out to find out the relationship of macro-economic variables and financial markets in perspective of Pakistan. Raza et al. (2013) examined the influence of foreign capital inflows and economic growth on market capitalization of Pakistan Stock market. Ali (2014) investigated the relationship between stock markets and interest rates in perspective of Pakistan. Irfan et al. (2013) investigated the two-way relationship between macro-economic variables and the stock market in Pakistan. Akhtar et al. (2017) investigated the relationship between the macro-economic variables and stock price in perspective of Pakistan for long and short-term horizons. However, as discussed earlier they lack the effect on mutual funds and their comparative analysis.

The distinctive feature of this study is to investigate the impact of macro-economic variables of three type of financial securities, namely equity, fixed income and balance (mix of fixed income and equity). More specifically we took three type of mutual funds representing equity, mutual funds, income funds and asset allocation funds from sharia compliant mutual funds and conventional mutual funds and investigate the difference of influence of macro-economic variables on three type of sharia complaint and conventional mutual funds.

In the following section, we briefly discuss the previous studies related to our objective of study, in section 3, we discuss about the theoretical background of the study. Section 4 
elaborates the performance of Islamic and conventional mutual funds in the context of Pakistan. Section 5 discusses the data and methodology of the study. Section 6 discusses the results of data that we have analyzed through different statistical and econometric techniques. In the last section, we draw some conclusions elaborating the major findings of the research followed by the key conclusion and recommendations.

\section{Literature REVIEW}

Akbar and Afiezan (2018) Study investigated the impact of corporate fundamentals and macro-economic variables on stock price of shariah compliant index in Jakarta (JII). Data was used from the period 2012 to 2016 . The study employed multi regression and found that corporate fundamentals like Debt to Equity, EPS, ROA significantly affect stock price while interest rate has no significant influence on stock price.

Raza et al. (2013) Study examined the influence of foreign capital inflows and economic growth on market capitalization of the Pakistan Stock market. The study used data from the period 1976 to 2011, employed ARDL bound testing and the result found that foreign capital inflow has strong positive influence on market capitalization.

Ali (2014) Study investigated the relationship between stock market and interest rate in perspective of Pakistan by using monthly data of ten years from Jan 2004 to Dec 2013. Research employed regression, correlation and other descriptive statistical analysis. Study found there is negative relationship between interest rate and stock market in other words interest has negative effect on stock price.

Aggarwal and Saqib (2017) Study examined the influence of macro-economic variables of India and USA on Indian Stock Market. Study used monthly data for the period from 20012016. The study employed a multivariate regression model and found that the GDP of USA, Gold price, S\&P Data, Foreign Intuitional Investor (FII India) have positive relationship with India's stock market and Exchange rate of Indian rupee against USD, Fiscal Deficit, Wholesale Price Index (WPI) India, Interest rate USA have negative impact on Indian stock market.

Irfan et al. (2013) investigated the two-way relationship between macro-economic variables and stock market in Pakistan. The study used data from the period Dec 1991 to Aug 2012. The study employed EGARCH model whereby macro-economic variables include GDP, Inflation and interest rate and KSE-100 index data as stock market data. The study concluded that there is no relationship between GDP and stock market returns and that interest has no significant impact on stock market returns.

Moya-Martínez et al. (2015) examined the relationship between interest rate and stock market return in the Spanish Stock market. The researcher used the Wavelet approach to find the relationship and the study concluded that relationship between interest rate and stock return varies across the time horizon. Long term interest has strong relationship with stock market returns and extent of relationship varies industry to industry and depends on time horizon.

Wasseja et al. (2015) examine the causal relationship between Kenya stock price and macroeconomic variables. Researcher used data from 1980 to 2012 annually and employed VAR (Vector Autoregressive) model to find the relationship. Study concluded and found the significant relationship between money supply, inflation rate, Treasury Bill Rate and exchange with stock price and found no significant relationship between GDP and Stock price. 
Kumar (2017) investigated the effect of macro-economic variables on Bombay Stock Exchange (BSE-100 India stock market). The study investigated external debts and inflation and macro-economic variables as independent variables and BSE-100 as dependent variable. The study employed Karl Pearson's coefficient of Correlation and Multiple Regression to ascertain the relationship. The study used data from the period 2001-2015 and concluded that external debts and inflation both have positive relation with the stock market.

Sinha and Kohli (2013) investigated the relationship between foreign exchange rate "USD/INR" and stock returns and examined the influence the effect of macro-economic variables have on the foreign exchange rate in India. The study used data from the period Jan-2006 to Mar-2012. The researcher employed the Least Squares Regression to ascertain the relationship. The study found no significant relationship between foreign exchange rate "USD/INR" and stock returns. The study found a significant influence on exchange rate while taking the inflation differential, lending interest rates and current account deficit as macro-economic variables.

Rizky et al. (2013) investigated the relationship between JII (Jakarta stock Exchange Islamic Index) and macro-economic variables. The study used the data from Jan-2000 to Dec-2010. Study employed co-integration and vector autoregression (VAR) to determine the relationship. The study took the exchange rate, industrial production, inflation rate and money supply as economic variables. The study concluded that exchange rate negatively effects JII in both short run and long run, Inflation (CPI) has negative relationship with JII in both short and long run, Money supply has negative relationship with JII in short run but positive effect on long run.

Akhtar et al. (2017) Study examined the relationship between the macro-economic variables stock price in perspective of Pakistan. The study employed Johansen Co-integration test, Vector Error Correction Model (VECM) to ascertain the relationship. Study used the data from Jan-2001 to May-2012. The study concluded the presence of long-term relationship between stock price and macro-economic variables. Industrial production showed positive relationship. Discount rate and inflation influence stock negatively while Exports, Exchange Rate and Money Supply depicted positive relationship with stock price.

Singh (2015) Study analyzed the relationship between Bombay Stock exchange (Indian Stock Market) and macro-economic variables. The study used the data from Jan-2007 to Mar-2014. The study employed Johansen's co-integration and vector error correction model to ascertain the relationship. The study took five macro-economic variables, wholesale price index, money supply, treasury bills rates, exchange rates and industrial production index. The study concluded the presence of long-term relationship between stock market and macro-economic variables. Stock price and wholesale price index have positive relationship. Money supply and interest rate have negative relationship with industrial production and exchange rate. Industrial production and the exchange rate have insignificant relationship with stock market price. Interest rate influence stock market index in both long run and short-run. Money supply effects stock price in long run. Stock market index impacts also wholesale price index in both short and long run.

Azizah and Satria (2016) investigated the relationship between Indonesian Sharia Stock Index (ISSI) and macro-economic variables as independent variables, namely, Consumer Price Index (CPI)-the proxy for inflation rate, interest rate, and exchange rate, and money supply, study employed co-integration VECM to ascertain long term and short-term relationship. The study found no relationship in short run between ISSI and macro- 
economic variables. The results showed significant long-term relationship between dependent and independent variables. In long term CPI significantly influencing ISSI. Interest rate and money supply have positive effect on ISSI.

\section{Theoretical Background of Islamic and Conventional Mutual Funds}

"Islamic finance is based only Shariah law. Shariah encourages the use of profit sharing and partnership schemes, and forbids interest (Riba), gambling and pure games of chance (Maysir), and short selling (Gharar: selling something that is not owned or that cannot be described in accurate detail; i.e., in terms of type, size, and amount). Conventional intermediation is based on interest to a large extent and permits for the transfer of risk. On the contrary, Islamic inter-mediation is asset-based, and is based on the sharing of risk and reward between the participants viz. the depositor, bank, and the entrepreneur", Mohsina Habib, Khalid U1 Islam (2014).

\section{Types of Mutual Funds}

Mutual funds are categorized into following types based on risk and time. By and large following three main categories (income, equity and mixed).

Income Funds: These are of the following types

- Money market funds: This type of funds consist of risk-free or no risk short term securities which gives very low yield. It is invested usually in government short term securities, T-bills, certificate of deposit etc. It provides security of principal amount and but gives very low return.

- Income funds: It consists of government and investment category corporate bonds. Its gives moderate yield as per risk basis. This type of investment takes low risk but investment holding period is long. Investor of these mutual funds wants steady income until maturity, being risk averse.

- Bonds funds: Every type of corporate bond is part of this mutual fund. This type of fund is actively managed to buy undervalued bonds and sell overvalued bonds. The return of this mutual fund is high as compared to income funds but bears higher risk. Junk and speculative bonds give high return with high risk. Objective of this funds is usually to get capital gain rather than steady income.

Nowadays, Sharia compliant Income funds are also offering regular and steady income. These funds invest in sharia compliant fixed income securities such as Sukuk.

Equity Funds: This type of fund can be categorized also in terms of risk, objective and investment period basis. Generally, below are major types. They invest in equity market and the aim of equity funds is to gain high return as compared to fixed income funds. It carries high risk also and risk of loss of money also exists. High return with capital appreciation creates different types of portfolio and steady regular income with moderate risk creates different type of mutual funds and, therefore, it is totally dependent on the objective of investor and style of portfolio manager. Sharia compliant equity mutual funds are created to invest in those stocks which are sharia complaint. Sharia compliant investment board has maintained list of stock and regularly updating list of sharia complaint stocks. Nowadays almost all over world including Pakistan, Sharia compliant index has been created including Dow Joan, S\&P-500. 
Balanced funds: It is the mixture of fixed income and equity securities to diversify risk and to get return objective. It is also called Asset Allocation Fund. These funds usually have 50\% weight in equities and $50 \%$ in fixed income securities in moderate style. If weight is around $70 \%$ to equity and $30 \%$ for fixed income than it becomes aggressive asset allocation and its opposite, $30 \%$ for equity and $70 \%$ in fixed income than it is called conservative approach for Asset Allocation mutual funds. In our study we took the moderate approach data and analyzed it with counterpart sharia compliant Asset Allocation mutual funds.

\section{Basic principal of Sharia Compliant (Islamic) Screening Criteria of Stocks:}

As per Islamic principal, buying and selling share or stocks of the company is perfectly legal but depends upon share of which company we are buying or selling. Keep in mind buying shares means you are becoming stock holder of the company or taking the ownership of the company as per proportionate of your share percentage. As per Islamic principles, Islamic scholars all over the world have defined basic guidelines to judge stock whether it falls under the Shariah compliant stock or not.

Core business of the company: Main Business of the company must be Halal. It must not be a haram business-like liquor, gambling, pork, pornography or any other haram business. It must not be any Riba (Interest) related business like conventional banks, insurance, leasing companies.

Proportion of Prohibited Income: If a company has more than one business and any one has haram business as per Islamic law than proportion of haram business will be calculated. Haram business must not be more than $5 \%$ and all stock holders must raise this issue in AGM to close haram business. If dividend received by stock holder than proportion of haram must be given in charity.

Debt to Equity Ratio: As per Islamic principal, interest bearing debt investment is prohibited. However, scholars have included the companies for investment who have debt to equity ratio not more than $33 \%$. Most shariah compliant index exclude the company whose debt to equity ratio is more than 33\%, including Dow Jones Islamic Market Index, FTSE Islamic Index. As per Islamic principal, preferred stocks are considered interest bearing debts. Dividend for preferred stock is interest and its prohibited in Islam.

Debt to Total Assets: Zero coupon bonds, Fixed Income Bonds, preferred stock is considered interest bearing debt. Islamic scholar has defined that Debt to Asset ratio should be less than $37 \%$.

Liquid Assets to Total Assets: Cash or cash equivalent assets to total assets should be less than $33 \%$. As per Islamic principal, the company must have more than $67 \%$ permitted traded non-liquid assets.

\section{Performance of Islamic and Conventional Mutual Funds in Pakistan}

The Islamic Equity market started growing in the mid-1990s although it is around us for last 40 years until 1999, there was no official Islamic index to benchmark the returns of Islamic Equity Funds against. In 1999 first two Islamic indices launched, Dow Jones and FTSE, Dow Jones Islamic Market Index (DJIMI) and the FTSE Global Islamic Index Series (GIIS) respectively. Nowadays, apart from Dow Jones and FTSE, MSCI Barra and Standard \& Poor's also offer numerous Islamic equity indices. 
Mohsina Habib, Khalid Ul Islam (2014). "Particularly due to the recent surge of liquidity, Islamic finance is gaining a significant place in the finance market place all over world. This in line is attracting both domestic and international money managers for tapping this market by offering Shariah-compliant funds. Indices were introduced world-over; even many financial institutions of developed countries such as Citibank, Barclays, Morgan Stanley, Merrill Lynch and HSBC are selling Islamic financial products. In India, the Standard \& Poor's launched S\&P BSE 500 shariah with the partnership of S\&P Dow Jones and Bombay Stock Exchange. The S\&P BSE 500 consists of 500 most liquid and largest Indian stocks trading at the BSE. The number of Shariah-compliant stocks in India is much higher than in Muslim countries put together, thus providing larger scope for Muslim investors. 61 percent Indian companies are found Shariah-compliant in India against 57 percent in Malaysia, 51 percent in Pakistan and a mere 6 percent in Bahrain".

Additionally, many well-known American and UK based stock exchanges like New York Stock Exchange and London Stock Exchange have launched Islamic indexes to monitor the performance of Shariah compliant firms which operate as per the Islamic based investment guidelines.

Ten-year report of Pakistan mutual funds

\begin{tabular}{|c|c|c|c|c|c|c|c|c|c|c|}
\hline Category & 2008 & 2009 & 2010 & 2011 & 2012 & 2013 & 2014 & 2015 & 2016 & 2017 \\
\hline Money Market & 114 & 3,282 & 32,050 & 77,312 & 150,509 & 124,418 & 117,385 & 66,681 & 49,658 & 70,549 \\
\hline Income & 105,714 & 56,403 & 49,085 & 39,954 & 87,620 & 56,438 & 63,336 & 80,476 & 98,037 & 69,960 \\
\hline Equity & 139,157 & 60,953 & 63,195 & 71,240 & 71,352 & 88,909 & 109,345 & 125,899 & 129,753 & 177,907 \\
\hline Capital Protected & 6,416 & 7,491 & 8,551 & 3,368 & 853 & 605 & - & 2,675 & 2,871 & 697 \\
\hline Fund of Funds - CPPI & - & - & - & - & - & - & 2,306 & 4,276 & 1,804 & - \\
\hline Aggressive Fixed Income & 35,781 & 23,143 & 14,019 & 9,340 & 7,862 & 10,130 & 12,345 & 11,694 & 14,056 & 13,887 \\
\hline Balanced & 16,978 & 8,343 & 6,349 & 4,841 & 4,147 & 4,092 & 3,731 & 4,645 & 4,489 & 5,976 \\
\hline Asset Allocation & 3- , 744 & $-1,790$ & $1-, 552$ & 2-, 277 & $3-, 136$ & 4,290 & 6,406 & 8,342 & 10,843 & 15,388 \\
\hline Fund of Funds & 1,833 & 1,000 & 1,182 & 1,223 & 1,291 & 1,190 & 141 & 171 & 1,739 & 4,178 \\
\hline Index Tracker & 534 & 319 & 223 & 374 & 343 & 315 & 419 & 460 & 452 & 520 \\
\hline Commodities & - & - & - & - & - & 140 & 304 & 340 & 367 & 214 \\
\hline $\begin{array}{l}\text { Conventional Voluntary } \\
\text { Pension Schemes }\end{array}$ & 305 & 349 & 571 & 655 & 1,101 & 1,865 & 3,263 & 7,989 & 7,302 & 9,115 \\
\hline $\begin{array}{l}\text { Shariah Compliant } \\
\text { Money Market }\end{array}$ & - & 624 & 5,224 & 6,353 & 7,762 & 7,088 & 5,189 & 13,483 & 5,920 & 7,337 \\
\hline Shariah Compliant Income & 6,618 & 5,868 & 6,132 & 20,888 & 29,944 & 36,414 & 36,783 & 21,028 & 29,692 & 31,508 \\
\hline Shariah Compliant Equity & 9,332 & 5,675 & 6,005 & 7,027 & 8,104 & 14,116 & 23,363 & 51,167 & 67,215 & 92,788 \\
\hline $\begin{array}{l}\text { Shariah Compliant Capital } \\
\text { Protected Fund }\end{array}$ & 579 & 582 & 637 & 724 & 443 & 1,304 & 2,972 & 3,015 & 1,771 & 244 \\
\hline $\begin{array}{l}\text { Shariah Compliant Fund } \\
\text { of Funds - CPPI }\end{array}$ & - & - & - & - & - & - & 11,533 & 20,671 & 9,168 & 379 \\
\hline $\begin{array}{l}\text { Shariah Compliant } \\
\text { Aggressive Fixed Income }\end{array}$ & 2,485 & 1,987 & 1,157 & 725 & 688 & 1,178 & 2,253 & 2,157 & 3,209 & 1,105 \\
\hline $\begin{array}{l}\text { Shariah Compliant } \\
\text { Balanced Fund }\end{array}$ & 3,340 & 2,501 & 2,189 & 2,290 & 2,334 & 3,772 & 6,955 & 3,493 & 4,822 & 9,516 \\
\hline $\begin{array}{l}\text { Shariah Compliant } \\
\text { Asset Allocation }\end{array}$ & 1,832 & 1,520 & 1,196 & 1,264 & 1,120 & 870 & 1,116 & 4,784 & 10,818 & 31,193 \\
\hline $\begin{array}{l}\text { Shariah Compliant } \\
\text { Fund of Funds }\end{array}$ & - & - & - & - & - & 699 & 927 & 3,269 & 23,679 & 61,411 \\
\hline $\begin{array}{l}\text { Shariah Compliant } \\
\text { Index Tracker }\end{array}$ & - & - & - & - & 289 & 901 & 1,176 & 1,159 & 882 & 1,881 \\
\hline $\begin{array}{l}\text { Shariah Compliant } \\
\text { Commodities }\end{array}$ & - & - & - & - & - & - & - & - & 321 & 457 \\
\hline $\begin{array}{l}\text { Shariah Compliant } \\
\text { Voluntary Pension Schemes }\end{array}$ & 466 & 530 & 729 & 903 & 1,640 & 2,957 & 4,912 & 5,596 & 11,502 & 16,142 \\
\hline TOTAL & 335,228 & 182,360 & 200,048 & 250,757 & 380,538 & 361,690 & 416,160 & 443,470 & 490,370 & 622,351 \\
\hline
\end{tabular}

Source: Mutual funds of Association of Pakistan (http://www.mufap.com.pk) 
KMI-30 was the first Islamic index created in the Karachi stock exchange (Now Pakistan stock exchange) in 2009. It was the combined effort of Al-Meezan Group and Karachi Stock Exchange. KMI-30 is recomposed semi-annually. Shariah compliant mutual funds have been accepted progressively as reflected by their share in Pakistan's mutual fund industry. Sharia compliant mutual funds' share had reached to 41\% (PKR 253 Billion) by June-2017 while Convention mutual funds share was at $49 \%$ (PKR 368 Billion). Sharia compliant Equity is the highest share $37 \%$ among sharia compliant mutual funds and $15 \%$ of all mutual funds. Conventional equity mutual funds have highest share 29\% of all mutual funds in Pakistan (Annual report -2017 by Pakistan Mutual fund Association of Pakistan). http://www.mufap.pk)

Overall, Pakistan's mutual fund industry grew in financial year 2017 by $26.9 \%$. NAV Increased from PKR 490 Billion to 622 Billion. Conventional mutual funds increased by 14.9\% (from 321 Billion to 368 Billion) and shariah compliant mutual funds increased by $50.27 \%$ (From 168 Billion to 253 Billion). (Annual report -2017 by Pakistan Mutual fund Association of Pakistan). Asset Management companies increased by 14\% from 185 to 211 . Due to vigorous growth in Shariah compliant mutual funds, almost every Asset Management company is offering Shariah compliant mutual funds.

\section{DATA AND METHODOLOGY}

\section{Data}

To attain the objective of the study, secondary annual data of return of mutual funds of conventional and Islamic mutual funds has been collected for the period 2007 to 2016 from MUFAP (www.mufap.com.pk), State Bank of Pakistan (www.sbp.org.pk) and Pakistan Stock Exchange (www.psx.com.pk). Data of Macro-economic variables were collected from website of World Bank (https://data.worldbank.org/) and Bureau of Pakistan Statistics (www.pbs.gov.pk/). Data is in panel form with 66 observations.

\section{Regression Analysis}

Methodology: We employ simple OLS as well as Panel OLS for regression before that we also employ Pearson correlation with 2 tailed-test of significance for comparison of factors and returns. The fundamental purpose of regression is to make a linear equation pertaining to the independent variable $X$, to the dependent variable $Y$. Regression assumes that both variables are measured on at least an interval level and should only be used if we think that this assumption is close to being met.

Regression coefficient: We apply multi-regression analysis to analyze the impact of Macroeconomic variables on the returns of equity, income and asset allocation of Conventional and Islamic mutual funds. In this analysis we consider Macro-economic variables as an independent variable while equity, income and asset allocation return of conventional and Islamic mutual funds as a dependent variable.

We employ the following regression equation

$Y^{\prime}=\alpha+\beta_{1} X_{1}+\beta_{2} X_{2}+\beta_{3} X_{3}+\beta_{4} X_{4+} \beta_{5} X_{5+} \beta_{5} X_{5}$

where

$\mathrm{Y}^{\prime}$ is the predicted Return of each mutual fund for given value of $\mathrm{x}, \alpha$ is Constant and $\beta 1$ to $\beta 5$ are Coefficients of Discount rate, Exchange rate, Inflation, Real GDP and Trade respectively. Following is the discussion of empirical studies that used these variables how these variables affect funds returns theoretically. 
Discount Rate: Discount rate is used to ascertain prevent value of stock. It discounts the future cash flow of any stock. Discount rate is kept in denominator. As discount rate rises, the price of stock will decrease. Discount rate and fixed income securities have strong positive relationship. Interest on fixed income securities depends of discount rate and other risk premium (Ali, 2014).

Exchange Rate: Naeem and Rasheed (2001) found no relationship of exchange rate with stock in Pakistan and Bangladesh in both horizons, short run and long run. Sinha and Kohli (2013) found negative relationship between exchange rate and stock market. Basically, exchange rate is generally tied with economy and foreign reserves and no direct relation with stock market.

Inflation: Inflation weakens the buying power of the household and it ultimately hits the industry and stock price negatively (Aggarwal and Saqib (2017). Inflation hits also fixed income negatively as it reduces the real interest rate, but it adjusts in long term horizon.

Real GDP: Theoretically, Stock market is tied with GDP, over the long-term, aggregate corporate earnings rise when the economy grows or vice versa (Herrmann, 2016). However, there are many examples the stock market is clearly disconcerted with economy. For last ten years, USA economy's growth has been getting slower at an average of $1.5 \%$ as compared to last 50 years' average was 3\%-3.5\% but the USA stock average growth rate is $5.6 \%$ (Herrmann, 2016).

Export \& Import: Theoretically stock market closely tied with industrial and business. Akbar and Afiezan (2018) concluded positive relationship corporate fundamental and stock market price and Singh (2015) concluded significant positive relationship industrial trading with stock market.

KSE-100 Index: As prices and mutual fund returns are tied to the index so theoretically it should have a strong positive relationship with them. However, every industry has own unsystematic risk or specific risk. If any industry or specific firm is facing unsystematic risk, then this relationship will not be strong. Moreover, fixed income securities do not have relationship with the stock market but if the stock market is volatile then the investor usually moves towards fixed income market to avoid risk.

\section{Our study included mutual funds of three type of Conventional and Islamic mutual} funds as dependent variables.

- $\quad$ Conventional Equity Mutual funds \& Sharia Compliant Equity Mutual funds

- Conventional Income Mutual funds \& Sharia Compliant Income Mutual funds

- Conventional Asset Allocation Mutual funds \& Sharia Compliant Asset Allocation Mutual funds

\section{RESULTS AND Discussion}

\section{Correlational Analysis}

Table 1 shows correlation coefficient analysis among all the variables. Results showed a strong positive correlation between discount rate and inflation, while strong negative correlation with GDP as expected. Similarly, strong negative correlation was witnessed between GDP and inflation. Higher inflation tends to increase discount rate and in turn slows the economy. However, surprisingly trade is positively affected by inflation, suggesting higher imports and exports could create demand pull inflation. Also discount 
rate is positively and strongly correlated with income funds of both Islamic and conventional types as they are used as benchmark, whereas weak effect on equity funds. Similarly, no relationship was found between income and equity funds of both Islamic and conventional origin. All equity finds (both conventional and Islamic) have strong positive relationship with market index, which they use as their benchmark, while income funds were not found to be correlated with market as expected. Surprisingly, there was a strong positive correlation between equity and asset allocation funds of both conventional and Islamic nature, whereas no relation between income and assets Allocation funds both Islamic and conventional types. Asset Allocation Funds were also found to be highly correlated with market index. This clearly showed Assets allocation are tied more towards equity and seems to be highly risky, this contradict Markowitz (1952) Modern portfolio theory presuming it to be in a minimum level of risk. In context of Pakistan, this theory doesn't seem to be valid. Lastly, all asset allocation and equity funds were found to be highly correlated with themselves with respect to Islamic and conventional types.

Table 1: Correlations

\begin{tabular}{|l|c|c|c|c|c|c|c|c|c|c|c|c|}
\hline & IsInR & KSE & DisR & ExR & Inf & RGDP & Trd & IsEqR & IsAssAllR & ConEqR & ConIncR & ConAssAllR \\
\hline IsInR & 1 & & & & & & & & & & & \\
\hline KSE & .366 & 1 & & & & & & & & & & \\
\hline DisR & $.757^{* *}$ & .263 & 1 & & & & & & & & & \\
\hline ExR & -.547 & -.367 & $-.630^{*}$ & 1 & & & & & & & & \\
\hline Inf & .506 & .342 & $.900^{* *}$ & $-.659^{*}$ & 1 & & & & & & & \\
\hline RGDP & -.499 & -.157 & $-.902^{* *}$ & .535 & $-.918^{* *}$ & 1 & & & & & & \\
\hline Trd & .458 & .329 & $.743^{* *}$ & -.486 & $.807^{* *}$ & $-.663^{*}$ & 1 & & & & & \\
\hline IsEqR & .052 & $.790^{*}$ & -.259 & .316 & -.395 & .283 & -.086 & 1 & & & & \\
\hline IsAssAllR & -.080 & .485 & -.545 & .286 & $-.615^{*}$ & .537 & -.352 & $.753^{* *}$ & 1 & & & \\
\hline ConEqR & .003 & $.886^{* *}$ & -.397 & .252 & -.491 & .483 & -.172 & $.913^{* *}$ & $.838^{* *}$ & 1 & & \\
\hline ConIncR & .482 & -.049 & .230 & -.177 & -.004 & -.212 & -.093 & .198 & .382 & .103 & 1 & \\
\hline ConAssAllR & -.124 & $.722^{*}$ & -.481 & .329 & -.589 & .446 & -.338 & $.924^{* *}$ & $.863^{* *}$ & $.913^{* *}$ & .235 & 1 \\
\hline
\end{tabular}

**Correlation is significant at the 0.01 level (2-tailed)

${ }^{*}$ Correlation is significant at the 0.05 level (2-tailed)

\section{Regression Analysis}

Table 2 shows the regression estimates of independent variable all Macro-Economic variables on dependent variables. The independent variables include:

- Discount Rate

- Exchange Rate

- Inflation

- Real GDP

- Export and Import as a percentage of GDP

- KSE 100 Index Return.

There are nine dependent variables namely Returns of funds pertaining to:

- Conventional Income

- Islamic Income

- Conventional Equity

- Islamic Equity

- Islamic Asset Allocation 
- Conventional Asset Allocation

- All Three Conventional combined

- All Three Islamic combined

- All Six Conventional and Islamic combined.

They are placed as dependent variables in model 1 to 9 respectively. Model 1 to 6 were done as time series OLS analysis for the period of 2007 to 2007. Whereas model 7 to 9 were panel least square analysis of the same period. In panel estimates, cross-section fixed effect was used with the help of dummy variable to account for differences among the funds. The results indicate that every macro-economic variable effect differently on all the returns and it is rational.

Discount rate and export \& import have positive effect on conventional Income mutual funds. Inflation and Real GDP have negative effect. Whereas exchange rate and KSE-100 returns have almost no effect on conventional Income mutual funds return. Discount rate has positive effect and Exchange rate, KSE-Index return does not make difference but, inflation has negative effect on Islamic Income mutual funds return. However, in contrast to conventional income funds, GDP has positive and trade has negative effect on Islamic income funds return. From the regression estimates of P-value and Coefficient, it can be stated that impact of all Macro-Economic factors on both conventional and Islamic Income mutual funds are statically insignificant. Accept for discount rate which is positive and significant in case of Islamic income funds.

Table 2: Regression Estimates

\begin{tabular}{|c|c|c|c|c|c|c|c|c|c|}
\hline & Model 1 & Model 2 & Model 3 & Model 4 & Model 5 & Model 6 & Model 7 & Model 8 & Model 9 \\
\hline Method & \multicolumn{6}{|c|}{ Ordinary Least Square (2007-17) } & \multicolumn{3}{|c|}{ Panel Least Squares (2007-17) } \\
\hline $\begin{array}{l}\text { Dependent } \\
\text { Variable: Mutual } \\
\text { Fund Return }\end{array}$ & $\begin{array}{l}\text { Conventional } \\
\text { Income }\end{array}$ & $\begin{array}{l}\text { Islamic } \\
\text { Income }\end{array}$ & $\begin{array}{l}\text { Conventional } \\
\text { Equity }\end{array}$ & $\begin{array}{l}\text { Islamic } \\
\text { Equity }\end{array}$ & $\begin{array}{l}\text { Conventional } \\
\text { Asset } \\
\text { Allocation }\end{array}$ & \begin{tabular}{|l} 
Islamic \\
Asset \\
Allocation \\
\end{tabular} & $\begin{array}{l}\text { All Three } \\
\text { Conventional }\end{array}$ & $\begin{array}{l}\text { All Three } \\
\text { Islamic }\end{array}$ & $\begin{array}{l}\text { All Six } \\
\text { Conventional } \\
\text { and Islamic }\end{array}$ \\
\hline \multirow[t]{2}{*}{ Constant } & 0.26 & -0.031 & -0.432 & 0.239 & 0.724 & 0.835 & 0.221 & 0.311 & 0.266 \\
\hline & $(0.24)$ & $(0.756)$ & $(0.435)$ & $(0.636)$ & $(0.33)$ & $(0.013)$ & $(0.711)$ & $(0.535)$ & $(0.474)$ \\
\hline \multirow[t]{2}{*}{ Discount Rate } & 0.437 & 1.072 & 0.118 & -0.096 & -1.676 & -1.999 & -0.481 & -0.234 & -0.357 \\
\hline & $(0.562)$ & $(0.034)$ & $(0.952)$ & $(0.958)$ & $(0.524)$ & $(0.05)$ & $(0.826)$ & $(0.899)$ & $(0.793)$ \\
\hline \multirow[t]{2}{*}{ Exchange Rate } & -0.001 & 0.00 & 0.001 & 0.002 & -0.002 & -0.001 & 0.00 & 0.00 & 0.00 \\
\hline & $(0.446)$ & $(0.69)$ & $(0.71)$ & $(0.329)$ & $(0.521)$ & $(0.156)$ & $(0.866)$ & $(0.989)$ & $(0.899)$ \\
\hline \multirow[t]{2}{*}{ Inflation } & -0.837 & -0.106 & 0.681 & -2.216 & -1.828 & -2.481 & -0.879 & -1.383 & -1.131 \\
\hline & $(0.247)$ & $(0.744)$ & $(0.699)$ & $(0.222)$ & $(0.442)$ & $(0.018)$ & $(0.653)$ & $(0.402)$ & $(0.355)$ \\
\hline \multirow[t]{2}{*}{ Real GDP } & -1.898 & 0.863 & 7.171 & -5.636 & -4.007 & -7.738 & -0.822 & -2.927 & -1.874 \\
\hline & $(0.339)$ & $(0.371)$ & (0.197) & $(0.264)$ & (0.545) & $(0.013)$ & $(0.882)$ & (0.529) & (0.587) \\
\hline \multirow{2}{*}{$\begin{array}{l}\text { Export + Import } \\
\% \text { of GDP }\end{array}$} & 0.016 & -0.032 & 0.427 & 0.771 & 0.396 & 0.412 & 0.285 & 0.379 & 0.332 \\
\hline & $(0.927)$ & $(0.71)$ & $(0.379)$ & $(0.13)$ & $(0.523)$ & $(0.072)$ & $(0.581)$ & $(0.385)$ & $(0.304)$ \\
\hline \multirow{2}{*}{$\begin{array}{l}\text { KSE } 100 \\
\text { Index Return } \\
\end{array}$} & -0.001 & 0.013 & 0.891 & 0.671 & 0.203 & 0.383 & 0.424 & 0.296 & 0.36 \\
\hline & $(0.973)$ & $(0.478)$ & $(0.001)$ & $(0.001)$ & $(0.149)$ & $(0.000)$ & $(0.000)$ & $(0.002)$ & $(0.000)$ \\
\hline \multicolumn{10}{|l|}{ Regression Statistics } \\
\hline R Sq. & 0.50005 & 0.83546 & 0.97837 & 0.96876 & 0.7498 & 0.98715 & 0.60820 & 0.5568 & 0.57304 \\
\hline Adj. R Sq. & -0.2498 & 0.58866 & 0.94594 & 0.9219 & 0.37454 & 0.9678 & 0.477602 & 0.4091 & 0.486077 \\
\hline F Stats & 0.66681 & 3.38518 & 30.1670 & 20.6744 & 1.99805 & 51.2497 & 4.65699 & 3.7704 & 6.588928 \\
\hline Sig. $F$ & 0.68741 & 0.12899 & 0.0027 & 0.00561 & 0.26202 & 0.00097 & 0.001558 & 0.0054 & 0.0000 \\
\hline Obs. & 11 & 11 & 11 & 11 & 11 & 11 & 33 & 33 & 66 \\
\hline DW stat. & & & & & & & 1.6757 & 1.7963 & 1.7448 \\
\hline Panel Effect & & & & & & & \multicolumn{3}{|c|}{$\begin{array}{l}\text { Cross-section fixed } \\
\text { (dummy variables) }\end{array}$} \\
\hline
\end{tabular}

With respect to equity-based funds, the results indicate that all macro-economic variables have positive effect on Convention Equity mutual fund returns and it is obvious with Real GDP and KSE-100 index return have strong positive effect. Inflation effects positively due to 
higher possible return is stock prices due to increase in revenues through price increase. GDP effect positively because it promotes economic activity backed by demand. Trade factor improves the performance of exports-based industry stocks. Islamic equity funds' returns have negative effect on Discount rate, Inflation and Real GDP. This contrasts with conventional equity funds. Discount rate seems to be understandable as higher rate increase required rate of return to equity stocks causing decrease in price. It also showed sharia compliant firms are adversely impacted with inflation maybe through its recessionary effect. Export + Import and KSE-100 Index return have a significantly positive effect on Islamic equity mutual funds return. From the regression estimates of P-value and Coefficient, it can be stated that impact of Macro-Economic" on both Islamic and Convention Equity mutual funds are statically insignificant except for market index where both have a positive and significant effect. This is understandable as these funds mimic their benchmark i.e. market index.

Model 5 and 6 showed the regression estimates on Islamic Asset Allocation mutual fund return. Discount rate, Exchange rate, Inflation, Real GDP have negative effect and export \& import, and KSE-100 Index have positive effect on both the Islamic and conventional Asset Allocation mutual funds return. This could be due to the mixed effect of debt and equitybased assets included in the funds. The negative effect with discount rate could be due to equity factor, inflation and GDP could indirectly cause higher discount rate causing decrease in stock prices. Moreover, trade and market index also mimic equity-based model 3 and 4. This also suggests Asset allocation are more inclined towards equity as compared to fixed income.

From the regression estimates of P-value and Coefficient, it can be stated that impact of all 6 Macro-Economic on Convention Asset Allocation mutual funds are statically insignificant. Whereas all were found to be statistically significant in case of Islamic Asset Allocation Funds return.

\section{Panel Regression Analysis}

Panel regression showed the estimates of all "6 Macro-Economic" independent variable on 1. Conventional mutual funds return (that contained all three conventional Income, conventional equity, conventional Asset Allocation mutual funds return). 2. Islamic mutual funds return (that contained all three Islamic Income, Islamic equity, Islamic Asset Allocation mutual funds return) and 3. All mutual fund returns (that contained all six types of funds). These were displayed in model 7,8 , and 9 respectively.

There was not much difference between conventional and Islamic funds. The results indicate that Discount rate, exchange rate, inflation and real GDP have negative effect on both types of funds returns. Whereas Trade and market Index have positive effect. This more closely tied to Asset allocation funds results, which themselves showed median effect among the returns. From the regression estimates of P-value and Coefficient, it can be stated that impact of all six Macro-Economic variables is almost same. All were found to be statically insignificant apart from market return.

Overall results in model 9 showed that Discount rate, inflation and real GDP have negative effect on mutual funds returns. Export + Import and KSE-100 Index have positive effect on mutual funds returns.

Overall, these results were in line with regression coefficient, depicting same result (heading 5.2.2). Furthermore, these results were in line with other studies such as Ali (2014); Moya- 
Martínez et al. (2015); Wasseja et al. (2015); and Akhtar et al. (2017) where they found a negative relationship between interest rate and inflation, and stock market. It also partially supports by Aggarwal and Saqib (2017) and Rizky et al. (2013) suggesting negative impact on exchange and interest rate on stock market. However, because of exchange rate, this study fully supported the results of Singh (2015) where they found that exchange rate has insignificant relationship with stock market price while Interest rate influence stock market index in both long run and short-run. In a nutshell, the empirical result validated other studies and showed the presence of relationship between macro-economic variables and mutual funds.

\section{CONCLUSION}

Overall funds behaved negatively with discount rate, inflation and GDP, whereas positively with trade and market index. The later was largely significant in all the cases. Apart from income funds that were affected positively with discount rate. This suggested that since the discount rate increases the required return of equities hence they witness large drop in prices conversely income funds' returns increased with higher discount rate. However, the effect of discount rate on conventional income funds were not as significant as compared to Islamic funds, furthermore, income funds were not affected by market index. Moreover, inflation and GDP that is usually backed by higher interest rates, also effect negatively overall returns. Positive relation to market and trade suggested that trade activities increase share returns so as market index. There was no significant difference in the behavior among the Islamic and conventional funds with respect to the above-mentioned factors. In an interesting finding, apart from other funds, Asset allocation funds behaved negatively with exchange rate as compared to others.

Moreover, conventional equity funds also behaved positively with discount rate, inflation and real GDP, whereas Islamic equity funds behaved inversely with all the three factors. Lastly, there was high correlation among both the equity and asset allocation based mutual funds (both Islamic and conventional). Both conventional and Islamic asset allocation funds were also found to be correlated with each other as well as with both equity-based funds possibly due to large portion of equity-based investment in their portfolio. It was also found that asset allocation funds had close resemblance to equity-based funds as compared to income-based funds in term of factors influencing their returns, those were found to be same. For example, Asset allocation funds were affected inversely by discount rate as compared to income funds that were directly related. Similarly, equity index has a positive and significant effect on both equity and asset allocation funds whereas week and insignificant effect with income funds. Both classes of funds also moved positively with trade, this suggested that most of the asset allocation funds have more portion of equity as compared to debt and could be consider highly risky.

Asset Allocation funds Return on per unit of risk is less as compared to equity return. Risk averse Investor must be cautious and analyze the risk associated with return. The main objective of the Asset Allocation mutual is to give investor opportunity to invest in diversified portfolio. Asset Allocation mutual funds created as per Modern portfolio theory (MPT) presented by Markowitz in 1952, describes how risk-averse investor creates a portfolio in minimum level of risk. If Asset allocation mutual funds have high share of equity than it is against the objective of the portfolio creation and against the MPT theory.

Present study confirms that macro-economic factors will remain effect Non-banking financial institution, but limitation of study should not be ignored as financial market of 
Pakistan is not developed as compared to developed countries. It is more volatile to political situation. Small and big political shocks some time crash markets. Global factors cannot be ignored like war in the region, foreign policy with developed and neighbor countries. Investor must be careful before investing in any risky ventures.

The study can further be extended by using time horizon to ascertain impact of macroeconomic variables on shariah compliant and conventional mutual funds on short term and long term basic.

\section{REFERENCES}

Aggarwal, P. and Saqib, N. (2017). Impact of Macro Economic Variables of India and USA on Indian Stock Market. International Journal of Economics and Financial Issue, 7(4), 10-14.

Akbar, T. Afiezan, A (2018). Determination of Sharia Stock Price through Analysis of Fundamental Factors and Macro Economic Factors. Account and Financial Management, 3 (10), 1739-1745.

Akhtar, Z.M.; Sohail, M. and Haroon, M (2017). Relationship between Stock Prices and Macroeconomic Variables: A Case Study of Karachi Stock Exchange. NUML International Journal of Business $\mathcal{E}$ Management. 12 (2), ISSN 2410-5392 (Print), ISSN 2521-473X (Online).

Ali, H. (2014). Impact of Interest Rate on Stock Market; Evidence from Pakistani Market. IOSR Journal of Business and Management (IOSR-JBM), 16 (1) 64-69.

Azizah, T.N. and Satria, D. (2016). The impact of macroeconomic fundamentals on the Indonesian Sharia stock index. Journal of Applied Economic Sciences 11(5).

Evidence from Pakistan. KASBIT Business Journal (KBJ), Vol. 8, No.1, 42-59, May 2015.

Herrmann, S. (2016), "Is there a Correlation between GDP Growth and Stock Market Returns?". https://www.wise-owl.com/investment-education/is-there-a-correlation-between-gdp-growthand-stock-market-returns.

Irfan, M.; Attari, J. and Safdar, L. (2013). The Relationship between Macroeconomic Volatility and the Stock Market Volatility: Empirical Evidence from Pakistan. Pakistan Journal of Commerce and Social Sciences, 7 (2), 309-320.

Kumar, J. (2017). An Analytical Study of the Impact of Macro Economic Variable on Indian Stock Market. Indian Journal of Research Paper, 7 (1), 79.96.

Markowitz, H. (1952). Portfolio selection. Journal of Finance 7, 77-91.

Mohsina Habib, Khalid Ul Islam (2014). An Empirical Assessment of Islamic Index: A Case Study of India. IRACST- International Journal of Research in Management \& Technology (IJRMT), Vol.4, No.3, ISSN: 2249-9563.

Moya-Martínez, P.; Ferrer-Lapena, R. and Escribano-Sotos, F. (2015). Interest rate changes and stock returns in Spain: A wavelet analysis. BRQ Business Research Quarterly, 18, 95---110.

Naeem, M. and Rasheed, A. (2001). Stock Prices and Exchange Rates: Are they Related? Evidence from South Asian Countries. Journal of Economics and Literature (JEL), JEL Classification: G15, C32.

Raza, S.A.; Jawaid, S.T. and Afshan, S. (2013). Is Stock Market Sensitive to Foreign Capital flows and Economic Growth? Evidence from Pakistan. MPRA 48399, https://mpra.ub.unimuenchen.de/48399/.

Rizky, M.; Sakti, P. and Harun, M.Y. (2013). Relationship between Islamic Stock Prices and Macroeconomic Variables: Evidence from Jakarta Stock Exchange Islamic Index. Global Review of Islamic Economics and Business, 1 (1) 2338-2619.

Singh, G. (2015). The Impact of Macroeconomic Fundamentals on Stock Prices Revised: A Study of Indian Stock Market. Journal of Economic Literature, JEL Code Classification: G10, E44, C22. 
Sinha, P. and Kohli, D. (2013). Modeling exchange rate dynamics in India using stock market indices and macroeconomic variables. Munich Personal RePEc Archive. MPRA, Paper No. 45816.

Wasseja, M.M.; Njoroge, E. and Mwenda, S.N. (2015). Investigation of the Granger Causal Relationship between Macroeconomic Variables and Stock Prices in Kenya. International Journal of Business and Economics Research, 4(3), 98-108.

$$
--0--
$$

